slaty black. The operculum also is, in some instances, almost entirely of a fleshy red colour, which in other specimens is considerably replaced, especially on the columellar side, by bluish-black streaks. The form of the young shells is very different from that of the adult, the wing-like expansions at both ends being entirely wanting, so that they have a much rounder appearance.

3. On two small Collections of African Lepidoptera recently received from Mr. H. H. Johnston. By A. G. Butler, F.L.S., F.Z.S., \&c.

[Received August 15, 1887.]

Dr. Sclater has recently submitted to me three boxes of Lepidoptera, chiefly Butterflies, forwarded by Mr. H. H. Johnston, F.Z.S., from the Cameroons and from the Rio del Rey to the west of these mountains. The first of these collections (consisting of thirteen Butterflies and three Moths) contains nothing of great interest, the best specimen being a Moth, possibly unnamed, of the genus Soloe, represented in the Museum collection by one specimen from Ashanti. The other species are:-Mycalesis martius and miriam, Fabr.; Junonia terea, Drury ; Aterica cupavia, Cram.; Romaleosoma ceres, Fabr.; Euralia anthedon, Doubl., and E. mima, var., Trimen ; Terias senegalensis, Boisd.; Nepheronia argia, Fabr.; Aletis fascelis, Linn., and its variety $A$. macularia, Fabr. : all wellknown species.

The second collection, which was unset, is far better, and may be dealt with in detail.

Lepidoptera from Rio del Rey.

\title{
RHOPALOCERA.
}

\section{Amauris hecate.}

Danais hecate, Butler, P. Z. S. 1866, p. 44. n. 5.

Euploea niavius, Hewitson, Gen. Diurn. Lep. pl. 11. fig. 3.

One good specimen.

2. Mycalesis asochis.

Mycalesis asochis, Hewitson, Ex. Butt. iii. Myc. pl. 7. figs. 46, 47 (1886).

A perfectly typical male.

3. Mycalesis martius.

Papilio martius, Fabricius, Ent. Syst. iii. 1, p. 219. n. 686 (1793).

One beautiful male. 


\section{4. Сумотноӥ USELda ${ }^{1}$.}

Harma uselda, Hewitson, Ex. Butt. iv. Har. pl. 4. figs. 13, 14 (1869).

\section{5. Сумотноё тнеодота.}

Harma theodota, Hewitson, Ex. Butt. iii. Har. pl. 1. figs. 3, 4 (1864).

\section{6. Сумотнӧ̈ Fumana.}

Harma fumana, Westwood, Gen. Diurn. Lep. p. 288. n. 3, note (1850).

One of each of the three above-named species was obtained, all more or less injured; the species of Cymothoë are probably strong-flying Butterflies, for they rarely come to hand in really good condition.

\section{Aterica tadema.}

Aterica tadema, Hewitson, Ex. Butt. iii. Aterica and Harma, figs. 10-12 (1866).

One pair obtained.

\section{Aterica lysandra.}

Papilio lysandra, Stoll, Suppl. Cram. pl. 29. figs. 3, $3 c$ (1790).

A good female was taken: the species rarely comes to hand.

9. Aterica gambiz.

Euryphene gambice, Feisthamel, Ann. Soc. Ent. France, 1850, p. 251 , pl. 9. fig. 2 .

A male.

\section{Aterica atossa.}

‥ Aterica atossa, Hewitson, Ex. Butt. iii. Eur. pl. 3. figs. 1, 2 (1865).

o. Aterica amaxia, Hewitson, $l$. c. At. and Eur. pl. 6. figs. 8, 9 (1866).

A single dwarfed female. In the Hewitson collection his $A$. atossa and A. amaxia stand near together in the same drawer; how he failed to see that they are sexes of one species, I cannot understand.

\section{Euryphene phantasia, var.?}

Euryphene phantasia, Hewitson, Ex. Butt. iii. Eur. pl. 2. figs. 9-11 (1865).

I am not quite sure that the single male obtained is not specifically distinct from Hewitson's insect; it has a white apical spot on the primaries, which is wholly wanting in the figure of the male from Old Calabar; moreover a specimen which we have from the Congo

${ }^{1}$ Males of this species stand in Hewitson's collection as a variety of $C$. coccinata and a female as that sex of $C$. sanguris, a second female from the same locality following it as type of $C$. uselda. 
and one from Old Calabar, in addition to the absence of this spot, have the subapical ochreous band narrower than in the specimen before me; the only difficulty is that a female in the Museum from Old Calabar corresponds far better with the Cameroons type than with Hewitson's males, none of which differ strikingly from the Congo male. As it is hardly likely that the differences between the Old Calabar and Cameroons males can be constant, though well marked in the specimens in the Museum, I have regarded them as the result of individual variation.

\section{Euryphene mardania.}

Papilio mardania, Fabricius, Ent. Syst. iii. 1, p. 249. n. 776 (1793).

A female of this common species.

13. EUPhadra RUSPina.

Romaleosoma ruspina, Hewitson, Ex. Butt. iii. Rom. pl. 2. figs. 6,7 (1865).

One male in good condition.

14. EUPHADRA XYPETE.

Romalensoma xypete, Hewitson, Ex. Butt. iii. Rom. pl. 2. figs. 8-10 (1865).

15. Euphedra johnstoni, sp. n.

o. Allied to $E$. losinga and luperca; nearest to the former, from which it differs as follows: primaries above with the costa, two large spots in the cell, and the apical half black, external angle suffused with purple; oblique ochreous subapical belt longer and broader; secondaries with a broad external belt of purple, from subcostal vein almost to anal angle, enclosing four large oval dark copper-brown spots : all the wings below with subapical white band, that of primaries representing the ochreous band of the upper surface, that of secondaries more transverse and tapering to below the third median branch; three black spots placed in the form of a triangle, and a terminal transverse black dash in all the discoidal cells. Expanse of wings 90 millim.

One male.

I have been unable to find a description of this very handsome species, which I have therefore been obliged to name.

\section{Euphedra ceres.}

Papilio ceres, Fabricius, Syst. Ent. p. 504. n. 257 (1775).

This abundant species is rarely absent from any West-African collection.

\section{Crenis occidentalium.}

Crenis occidentalium, Mabille, Bull. Soc. Zool. de France, vol. i. p. 275 (1876). 
Crenis vadimonis, Druce, Ent. Month. Mag. xiv. p. 226 (1878).

Crenis ribbei, Dewitz, Nova Acta Acad. Leop.-Carol. 1879, pl. xxvi."fig. 3 .

The above is the correct synonymy of this species; and it is a singular thing that this Butterfly, which had long stood in collections as a variety of the Natal insect, should have suddenly been taken up and described in three consecutive years.

18. Catuna crithea.

Papilio crithea, Drury, Ill. Exot. Ent. ii. pl. 16. figs. 5, 6 (1773).

\section{Neptis Agatha.}

Papilio agatha, Cramer, Pap. Exot. iv. pl. 327. A, B (1782).

20. Atella columbina.

Papilio columbina, Fabricius, Ent. Syst. iii. 1, p. 148. n. 453 (1793).

\section{Ergolis enotrea.}

Papilio enotrea, Cramer, Pap. Exot. iv. pl. 236. A, B (1782).

22. Junonia sophia, var.

Papilio sophia, Fabricius, Ent. Syst. iii. 1. p. 248. n. 771 (1793).

A rather pale and large speeimen.

23. Junonia ETHYra.

Salamis ethyra, Feisthamel, Ann. Soc. Ent. France, 1850, p. 250.

24. Kallima rumia.

Kallima rumia, Westwood and Hewitson, Gen. Diurn. Lep. p. 325. n. 5, pl. 52. fig. 2 (1850).

\section{Charaxes cynthia.}

Charaxes cynthia, Butler, P.Z.S. 1865, p. 626. n. 12, pl. 36 . fig. 3 .

A fine male of this handsome species was obtained. It appears still to be a rare insect, at any rate $I$ never see it in African collections sent to the Museum to be selected from.

\section{Charaxes imperialis.}

o. Charaxes imperialis, Butler, Trans. Ent. Soc. 1874, p. 531, pl. xi. fig. 3 .

The female of this splendid Butterfly, unfortunately a little damaged, is in the collection. It differs from the male in its greatly superior size; the blue band of primaries reduced to a short externally excavated bar, terminating above in a white spot, above this are two parallel bent series of four and six white spots respectively, and the white spot in the cell is enlarged; in the secondaries the blue band differs chiefly in being greener, excavated or arched in 
front and ending in two white spots; the white spot of the male is much enlarged and quadrate, and the submarginal and marginal markings are larger and buff-coloured instead of blue.

27. Telchinia serena.

Papilio serena, Fabricius, Syst. Ent. p. 461. n. 76 (1775).

One male of this common species.

28. Abisara tantalus.

Sospita tantalus, Hewitson, Ex. Butt. ii. Sosp. pl. 1. fig. 1 (1861).

\section{LyCenesthes LaRydas.}

Papilio larydas, Cramer, Pap. Exot. iii. pl. 282. H (1782).

This and the other species of Lyccenesthes in the collection were all represented by males only; females of this genus seem to be rare.

\section{LyCANESTHES Ligures.}

Lyccenesthes ligures, Hewitson, Trans. Ent. Soc. 1874, p. 349.

31. Lycenesthes docilis, $\mathrm{sp} . \mathrm{n}$.

o. Above dark slaty blue, brownish towards the outer margins of the wings; fringes grey-brown, with darker subbasal line and white tips; costal and abdominal borders of secondaries brown: body blackish : under surface dove-grey, with the markings indicated only by their white edges, very similar in their general arrangement to those of $L$. ligures, excepting that an additional irregular macular band runs from the costa across the middle of the discoidal cell in all the wings; the ocelli of the secondaries are also reduced to small distinct black spots, without any orange iris or metallic blue sealing; venter white. Expanse of wings 32 millim.

One male only of this very distinct species was obtained.

\section{Azanus occidentalis, sp. $n$.}

$\sigma^{*}$. Nearest to $A$. gamra, chiefly differing on the upper surface in the absence of the black anal spots of the secondaries; below, the primaries differ in the darker colouring of all the markings, in having a round white-bordered blackish spot in the cell and an oblique grey dash nearer to the base below the cell, the subapical oblique band more oblique, and the submarginal white line beyond it widened to a band; secondaries chalky white, all the markings sharply defined, but without white borders, the markings beyond and below the cell black and composed of distinct spots like the others; anal ocelli small. Expanse of wings 26 millim.

One male only. We have it also from Sierra Leone, and in the Hewitson cabinet it stands as the A. moriqua of Wallengren, which is a totally distinct species, found commonly at Natal. A. gamra is the common species of Beirût. 
33. Allotinus zymna, var.?

Pentila zymna, Hewitson, Gen. Diurn. Lep. pl. 76 . fig. 7 (1852).

One example with very narrow border to the secondaries and slightly browner under surface. As it is possible that these may only be individual differences, I have not ventured to consider the specimen distinct.

34. Neopithecops elorea.

Papilio elorea, Fabricius, Ent. Syst. iii. 1, p. 194. n. 603 (1793).

35. Iolaus faunus.

Papilio faunus, Drury, Ill. Exot. Ent. ii. pl. 1. figs. 4, 5 (1773).

36. Tatura lebena.

Thecla lebena, Hewitson, Descr. Lyc. p. 9. n. 21 (1868); Ill. Diurn. Lep. p. 127. n. 202, pl. 51. figs. 266-7 (1869).

37. Mylothris Chloris.

Papilio chloris, Fabricius, Syst. Ent. p. 473. n. 129 (1775).

One pair.

38. Mylothris asphodelús, sp. $n$.

б. White; primaries above with the basal fourth gamboge-yellow ; base of costa greyish, a broad apical black border, tapering on costal margin, interrupted so as to form a separate spot at the end of second median branch and followed by a black dot at the end of first median branch; secondaries with six marginal black spots: body greyish, quite normal. Under surface white, slightly pearly : all the wings with rather large black spots on the outer margin; primaries with the basal yellow patch more restricted and rather more golden than above, the apical area tinted with sulphur-yellow; base of secondaries bright yellow towards costa : body below white, legs with a black longitudinal stripe; a black spot on each side of the anal valves. Expanse of wings 57 millim.

One male only; it mimics Phrissura sylvia.

39. Terias Senegalensis.

Eurema senegalensis, Hübner, Zutr. exot. Schmett. figs. 969, 970 (1837).

A female specimen.

40. Terias boisduvaliana.

Terias boisduvaliana, Mabille, in Grandid. Hist. Madag. ii. Atlas, i. pl. 32. figs. 4,5 (1885).

A dwarfed male.

41. Catopsilia hyblea.

Callidryas hyblaa, Boisduval, Sp. Gén. Lép. i. p. 612. n. 7 (1836).

A female. 
42. Phrissura syluia ${ }^{1}$.

Papilio sylvia, Fabricius, Syst. Ent. p. 470. n. 115 (1775).

One male specimen was obtained.

43. Papilio similis.

Papilio similis, Cramer, Pap. Exot. i. pl. 9. B, C (1779).

44. Papilio ucalegon.

Papilio ucalegon, Hewitson, Exot. Butt. iii. Pap. pl. 7. fig. 19 (1865).

\section{Papilio policenes.}

Papilio policenes, Cramer, Pap. Exot. i. pl. 37. A, B (1779).

46. Papilio erinus.

Papilio erinus, Gray, Cat. Lep. Ins. Brit. Mus. i. p. 35, n. 127 (1865).

\section{Papilio hesperus.}

Papilio hesperus, Westwood, Arc. Ent. i. pl. 48 (1843).

Two fine male specimens of this magnificent species.

48. Papilio cyprafafila.

Papilio cyprceafila, Butler, Ent. Month. Mag. v. p. 60 (1868).

49. Hesperia forestan.

Papilio forestan, Cramer, Pap. Exot. iv. pl. 391. E, F (1782).

50. Hesperta bixa.

Papilio bixa, Linneus, Mus. Lud. Ulr. p. 335 (1764).

51. Astictopterus johnstonir, sp. n.

Dark chocolate-brown ; primaries crossed obliquely near apex by a semitransparent amber-yellow belt from costa to just below second median branch near outer margin, the inner edge of the band almost straight, the outer edge arched, so that it forms almost a half-moon shape ; costa of secondaries pale; sides of palpi, front edge of collar, and under surface of tarsi orange ; primaries below with pale brown internal border. Expanse of wings 57 millim.

Not nearly allied to any known species.

52. Thanaos westermanni.

Hesperia westermanni, Latreille, Enc. Méth. ix. p. 791. n. 167 (1823).

\section{Tagiades flesus.}

Papilio flesus, Fabricius, Spec. Ins. ii. p. 135. n. 621 (1781).

1 I find that the species of this group belong to Phrissura, which will now contain P. phaola, P. sylvia, P. eudoxia, P. coniata, P. polisma, and P. illana.

Pruc. Zoor. Soc.-1887, No. XXXVIII. 


\section{TAgiades BRIgIda, var.}

Antigonus brigida, Plötz, Stett. ent. Zeit. 1879, p. 361. n. 32.

But for the fact that the type of this species was from the Cameroons, coupled with the remark "Diese Art sieht Trichoneura, Feld., ähnlich," I should certainly have failed to identify it; the description, "Hind wings above with broad straw- or orange-yellow borders," hardly represents an insect in which more than half the hind wing is bright orange; nor does the statement that there are "six hyaline white points" in the front wings answer to a specimen with ten. However, I am unwilling to risk describing as new a species which may be subject to variation and therefore already described as above, or which may have been incorrectly described.

\section{Ceratrichia argyrosticta?}

Apaustus argyrosticta, Plötz, Stett. ent. Zeit. 1879, p. 358. n. 22.

One example so nearly approaching the description of the above that I think it can hardly be distinct.

\section{HETEROCERA.}

\section{Pseudopontia paradoxa.}

Globiceps paradoxa, Felder, Pet. Nouv. Ent. n. 8 (1869).

Gonophlebia paradoxa, Felder, l. c. n. 24, p. 95, fig. (1870).

Pseudopontia calabarica, Plötz, Stett. ent. Zeit. 1870, p. 348, pl. 2. figs. $1 a-f$.

I canuot understand why this insect has been referred to the Butterflies; the structure of the antennæ and the neuration are altogether peculiar. In my opinion the genus is more nearly related to the Chalcosiid moths.

\section{Otroeda occidentis.}

Otroeda occidentis, Walker, Cat. Lep. Het. ii. p. 403. n. 2 (1854), One male example.

58. Chrysopoloma rudis.

Lasiocampa rudis, Walker, Cat. Lep. Het. Suppl. ii. p. 561 (1865).

59. Pitthea continua.

Pitthea continua, Walker, Cat. Lep. Het. ii. p. 463. n. 1 (1854).

60. Cyligramma latona.

Phalana-Noctua latona, Cramer, Pap. Exot. i. p. 20, pl. 13. B (1779).

\section{Azazia rubricans.}

Ophiusa rubricans, Boisduval, Faune, Lép. Madag. p. 106. n. 11, pl. 16. fig. 1 . 


\section{$2 \mathrm{BHL}$ Biodiversity Heritage Library}

Butler, Arthur G. 1888. "On two small collections of African Lepidoptera recently received from Mr. $\mathrm{H}$. H. Johnston." Proceedings of the Zoological Society of London 1887, 567-574.

View This Item Online: https://www.biodiversitylibrary.org/item/91212

Permalink: https://www.biodiversitylibrary.org/partpdf/67511

\section{Holding Institution}

Natural History Museum Library, London

\section{Sponsored by}

Natural History Museum Library, London

\section{Copyright \& Reuse}

Copyright Status: Public domain. The BHL considers that this work is no longer under copyright protection.

This document was created from content at the Biodiversity Heritage Library, the world's largest open access digital library for biodiversity literature and archives. Visit BHL at https://www.biodiversitylibrary.org. 